\title{
LIETUVOS KARIUOMENĖS ŠAULIŲ RENGIMO SISTEMOS ATITIKTIS MOKYMO ŠAUDYTI IŠ PISTOLETO TENDENCIJOMS
}

\section{Laurynas Česūnas, Rosita Kanapeckaitė}

\author{
Generolo Jono Žemaičio Lietuvos karo akademija
}

\begin{abstract}
Anotacija. Publikacijos tikslas - atskleisti, kokiu būdu ir kokia metodika taikant rengiami Lietuvos kariuomenès kariai šaudyti iš pistoleto. Karių mokymas šaudyti iš pistoleto, kasmetis šaudymo iš pistoleto ịūužiu testavimas nepakankamas, kad jie būtų tinkamai parengti greitai reaguoti ir efektyviai naudoti ši ginkla artimojo mūšio sąlygomis. Nustatyta, kad JAV ir Švedijos policijos pareigūnai 83 proc. atveju pistoletus naudojo šaudydami iki 15 m, JAV pareigūnai 96 proc. atveju - iki 15 jardu, t. y. iki 13,7 m, esančius taikinius. Švedijos policijos pareigūnai 42 proc. susidūrimu naudojo ginkla iki $3 \mathrm{~m}$, JAV pareigūnai 50 proc. visu ginklo panaudojimo atveju - iki 4,57 m atstumu. Lietuvos kariuomenès šaudymo iš individualaus ginklo testo (KŠIGT) ir šaudymo iš papildomo ginklo ìvertinimo (ŠPGI) metu kariai šaudo 15-25 m nuotoliu. Taip pat atskleidžiama, kad „Šaudymo vadove“ itvirtintas reikalavimas, kad kariai, pirma kartą šaudantys iš pistoleto, turi išeiti visq mokymo naudotis ginklu programa, tačiau tokios programos nèra. Atlikta literatūros analizé leidžia manyti, kad Lietuvos kariuomenès šaulių rengimo sistema turi būti peržiūrèta iš esmès, o atlikti pakeitimai grịsti moksliniais tyrimais ir pažangiais didaktiniais ir metodiniais principais.
\end{abstract}

Reikšminiai žodžiai: šaudymas, pèstininkai, šauliu ginklai, pistoletai, šauliu rengimo sistema, artimasis mū̌̌sis.

\section{Ivadas}

Pagrindinis kariuomenès uždavinys (angl. mission) - karo metu ginti valstybę. Lietuvos kariuomenè tam nuolat rengiasi ir prireikus vykdys šią funkciją. Kartu visiems žinoma, kad kariuomenès sprendžia iškeltas užduotis griaudamos ir atimdamos gyvybes (Watts, 1996).

Lietuvos kariuomenès personalo profesinis ugdymas būtinas kariuomenès uždaviniams ịgyvendinti taikos ir ginkluotos gynybos metu. Gerai parengtas personalas - kariuomenės pergalès garantas. Karių mokymas šaudyti yra viena kertinių jų rengimo sričių. Lietuvos kariuomenès šaulių rengimo sistema (Lietuvos kariuomené, 2020) turètų užtikrinti, kad kariai bus tinkamai, pagal nustatytus standartus, parengti vykdyti skirtas funkcijas ar (ir) užduotis taikos ar karo sąlygomis. Ginklo naudojimas taikos sąlygomis padidina šaulio atsakomybę ir pakelia kompetencijų, 
reikalingų šaudant iš ginklo, kartelę. Šaudymas per treniruotes gana tiksliai reglamentuotas, bet taiklus šūvis, greitas iššovimas uždaroje, apgyvendintoje vietoveje, kur paleista kulka gali ir nepataikyti ị taikinį, kelia nemažai ne tik techninių, bet ir moralinių - šauti ar nešauti? - klausimų.

Tyrimo problema - esama Lietuvos kariuomenès šaulių rengimo sistema, pagal kurią šaulys mokomas šaudyti iš pistoleto, nesudaro prielaidų ịgyti pakankamai igūdžių, leidžiančių greitai ir efektyviai ginklą panaudoti artimojo mūšio sąlygomis.

Tyrimo tikslas - atskleisti šaulių rengimo sistemos taisytinus aspektus atsižvelgiant ị kitų šalių mokymo šaudyti iš pistoleto ir praktinio jų naudojimo patirtį.

Tyrimo objektas - Lietuvos kariuomenès šaulių rengimo sistemos atitiktis mokymo šaudyti iš pistoleto tendencijoms.

\section{Tyrimo uždaviniai:}

1. Apibūdinti Lietuvos kariuomenès šaulių rengimo sistemą atsižvelgiant $\mathfrak{i}$ bendras mokymo šaudyti iš pistoleto tendencijas.

2. Palyginti Lietuvos kariuomenès šaulių rengimo sistemą su kitų šalių rengimo šaudyti iš pistoletų ir jų praktinio naudojimo aspektais.

3. Atskleisti šauliu rengimo sistemos - mokymo šaudyti iš pistoleto - problemas, rengiant juos laikyti ginklo valdymo testą (GVT), ir pateikti šios sistemos tobulinimo gaires.

Tyrimo metodai: mokslinès, metodinès literatūros, dokumentų analizè, statistinių duomenų lyginimas ir interpretavimas, sintezè.

Kariuomenès karinių pajègų rengimą reglamentuoja Lietuvos kariniu pajegu rengimo doktrina (D-LK-07). Leidinyje „Kolektyvinio rengimo vadovas (A-LK-07.02)“ reglamentuotas kolektyvinis rengimas kariniuose vienetuose, detalizuota, kaip jis turi būti planuojamas, organizuojamas ir vertinamas. Šaudybos mokymas apima ne tik individualuji, bet ir karinio vieneto rengimą sutartinai veikti artimomis mūšiui sąlygomis. Šaudymo planavimo ir organizavimo, kontroles ir saugos taisyklès (péstininku ginklai) (A-LK-004) skirtos kvalifikuotam personalui, kuris planuoja, organizuoja kovinio šaudymo pratybas ir jose dalyvauja, ir nekvalifikuotam personalui, organizuojančiam ir vykdančiam šaudymo pratybas, kuriose naudojami tik imitaciniai šaudmenys. Kovinis šaudymas yra rizikinga veikla, nes naudojami koviniai šaudmenys ir ginklai, todèl ir nedidelè jo planavimo, organizavimo ar šaudymo užduočių vykdymo klaida gali turèti fatališkų padarinių šaudymo pratybų dalyviams. Saugos reikalavimų išmanymas ir vykdymas yra neatsiejama šaudybos mokymo dalis.

Lietuvos kariuomenè ir JAV sausumos pajègos (angl. Army) (Headquarters, 2019; Šaudymo vadovas, 2020) taiko skirtingas šaulių rengimo sistemas ir strategijas. JAV šaudymo iš pistoleto strategija, nepaisant karių skaičiaus ir su tuo susijusio rengimo kompleksiškumo skirtumų, demonstruoja pažangius didaktinius ir metodinius karių rengimo aspektus. Tai liudija psichologinio rengimo akcentavi- 
mas, apibrèžtas žinių, igūdžių laukas, standartizuotas karių vertinimas, virtualiosios realybės technologijų taikymas rengiant karius (Headquarters, 2019).

Akademinių straipsnių šaudymo iš pistoleto temomis ir su tuo susijusiais karių rengimo klausimais lietuvių kalba nèra arba nepavyko rasti. Viena kariuomenès užduočių taikos metu ar nepaprastosios padèties atveju - remti civilinę administraciją (Lietuvos Respublikos Seimas, 1998). Tad policijos ir kariuomenès pareigūnų, karių aplinka (vieta), kurioje dirbama (tarnaujama), yra ta pati ar panaši, todèl publikacijoje remtasi Lietuvos ir užsienio policijos pareigūnų sukaupta patirtimi ir statistiniais duomenimis, susijusiais su kovinio ginklo panaudojimo aplinkybėmis ir kitais pareigūnų rengimo metodiniais aspektais.

Šaudymo iš pistoleto, policijos pareigūnų rengimo temomis Lietuvoje daugiausia rašo vienas autorius - Viačeslavas Čigrinas (Viačeslav Čigrin), nagrinėjantis policijos statistinius duomenis ir būsimų policijos pareigūnų rengimo šaudyti iš pistoleto aspektus (Čigrin, 2012, 2014, 2016b, 2016a). Policijos pareigūnai naudoja ginklus uždaroje, ribotoje zonoje (patalpose, gatveje ir t. t.), kurioje yra didelè rikošeto galimybè, taip pat reali tikimybė sužaloti pašalinius asmenis (Pataševas, 2002), be to, bet kokio kalibro ir kulkos derinys negarantuoja žaibiško oponento neutralizavimo, todèl yra tik vienas būdas tai padaryti - pažeisti jo centrinę nervų sistemą (galvos, stuburo smegenis) (Čigrin, 2017). Aveni (2003) straipsnyje teigia, kad Niujorko policijos departamentas policijos pareigūnų šaudymo ịūdžius tikrindavo jiems šaudant iš $22,8 \mathrm{~m}$ (25 jardų) nuotolio, nors daugelis nepataikydavo ị taikinį, savo teiginius, kad būtina keisti mokymo programą, argumentavo nagrinèdamas šaudymo iš pistoleto atstumus ir jo efektyvumo (kiek procentų išautų kulkų pataiko i taikini) duomenis.

Baziniai ịgūdžiai dažniausiai ugdomi naudojant standartines (visiems tas pačias) mokomąsias programas. Bihevioristinis ugdymo požiūris taikomas, kai reikia ịvaldyti tam tikrus ịgūdžius ir procedūras, kai geri veiksmai skatinami, o už netinkamus - baudžiama, kognityvinis - kai norima perteikti teorinę informaciją. Šie ugdymo požiūriai vienodai veikia policijos pareigūnus: jie būna apatiški, sunkiai ịsitraukia į veiklą. Labai svarbus policijos pareigūnų ugdymo aspektas yra jų rengimas priimti tinkamus sprendimus neapibrěžtomis, neaiškiomis aplinkybėmis (Johnsen, Espevik, Saus, Sanden ir Olsen, 2016).

Skirtingi autoriai pateikia panašius duomenis ir pabrèžia, kad koviniai susišaudymai vyksta artimoje aplinkoje (nedideliu atstumu), todèl tam besirengiančiuju galvose skamba šie pagrindiniai leitmotyvai: treniruokis, kaip kariausi, greitis ir taiklumas - sèkmès garantas. Pareigūnai turi greitai priimti sprendimus, mokymas turi vykti imituojant hipotetinius scenarijus (Aveni, 2003; Bratton, 2015; Johnsen et al., 2016; Petersson et al., 2017).

Išanalizavus negausias, tačiau reikšmingas publikacijas ir Lietuvos kariuomenès leidinius galima teigti, kad Lietuvos kariuomenès šaulių rengimo sistema nèra tirta. Atlikus Lietuvos ir užsienio šalių autorių publikacijų turinio analizę buvo nustatytos rengimo tendencijos ir išskirti tobulintini aspektai. Šis tyrimas remiasi 
samprotavimu, kad karys tinkamai yra parengtas tada, kai jo įgūdžiai patvirtinami kasmetinio kovinio šaudymo testo, kuris privalomas visiems kariams, rezultatais. Jị išlaikius, rengimas gali būti tęsiamas arba ne.

\section{Lietuvos kariuomenès šaulių rengimo sistemos dalis - mokymas šaudyti iš pistoleto}

Lietuvos kariuomenejje šaulio rengimo sistemą reglamentuoja Lietuvos kariuomenès vado $2020 \mathrm{~m}$. kovo $18 \mathrm{~d}$. įsakymu Nr. V-374 patvirtintas leidinys „Šaudymo vadovas (A-LK-07.1.01.1)“. Leidinyje išdèstyti šaudymo mokymo reikalavimai. „Jie turi būti igyvendinti visuose kariniuose vienetuose, kad būtų užtikrintas kovinio šaudymo efektyvumas realiomis mūšio sąlygomis“ (Šaudymo vadovas, 2020 , p. iv). Karinis vienetas - tai „bet kokio dydžio kiekvienas patvirtintos struktūros kariuomenès vienetas, turintis bendrą užduotị. Karinis vienetas gali būti: padalinys, dalinys, junginys, darinys, komanda. Karinis vienetas gali būti nuolatinis ir laikinasis<...>“ (Lietuvos Respublikos terminu bankas). Šị leidinị rengia Mokymo ir doktrinų valdyba, tvirtina - Lietuvos kariuomenès vadas. „Šaudymo kursas A-LK-001 (pėstininkų ginklai)“ (nuo 2020 m. reglamentuoja „Šaudymo vadovas“ aut. pastaba) yra pagrindinis dokumentas, reglamentuojantis Lietuvos kariuomenès reguliariujų, teritorinių ir rezervo vienetų šaudybą" (Lietuvos kariniu pajegu rengimo doktrina, 2013, p. 3-39). Tai suponuoja taisyklę, kad kiekvienas Lietuvos kariuomenès karys ir karinis vienetas turi būti rengiamas šaudyti taikant „Šaudymo vadove" aprašytus šaudymo reikalavimus.

Karių funkcijos mūšyje skiriasi priklausomai nuo jų specializacijos, vadinasi, ir jų rengimas turi skirtis. Šị teiginị pagrindžia ir „Šaudymo vadove“ išdèstytos bendrosios nuostatos, kad „šaudymo reikalavimai pėstininkams ir kitų padaliniu kariams skiriasi“" (Šaudymo vadovas, 2020, p. 1-1). Kariai skirstomi ị pėstininkus ir kitų padalinių karius. Žodžio péstininkas reikšmè - „pèsčiosios kariuomenès karys“ (Dabartinés kalbos žodynas), o „batalionas būna: pėstininkų (mechanizuotasis, motorizuotujų pėstininkų, motorizuotujų šaulių, šaulių, pėstininkų aeromobilusis), tankų, parašiutų desantinis <... “" (Lietuvos Respublikos terminu bankas). Kariu rengimas šaudyti priklauso nuo to, kokiai kategorijai jie priklauso. Kariai skirstomi ị pėstininkus ir kitų padalinių karius. Tikslaus paaiškinimo „Šaudymo vadove“ nepateikta. Ar pėstininkas yra kiekvienas karys, kuris tarnauja pėstininkų batalione? O kariai, netarnaujantys pėstininkų batalione, ar priskiriami kitiems kariams? Taigi karių klasifikacijos klausimas išlieka aktualus ir galètų būti kito tyrimo ir publikacijos objektas, nes tik tinkamai priskyrus kari tam tikrai kategorijai bus sudarytos sąlygos šaulių rengimo sistemos nuostatoms iggyvendinti, nes pestininkams yra keliami daug didesni rengimo reikalavimai.

Pagrindiniai pėstininkų ir kitų padalinių karių rengimo skirtumai yra akivaizdūs: pèstininkai rengiami kovoti karinių vienetų sudètyje, o kiti kariai turi gebėti taikliai šaudyti tik individualiai, pėstininkai - greitai reaguoti ị pasirodžiusị priešą, 
taip pat nukauti (ar sulaikyti) priešą iš įvairių šaudymo padečiuų, judedami ar iš už priedangos ir dar bet kokiomis sąlygomis, visi kiti kariai - taikliai šaudyti iki $400 \mathrm{~m}$ nuotoliu (išskyrus kulkosvaidininkus). Nors nèra atskirai apibrežta, aišku, kuo skiriasi terminai „nukauti“, „sulaikyti“ ir „taikliai šaudyti“ (žr. 1 lentelę) (Šaudymo vadovas, 2020).

1 lentelè. Reikalavimai šauliams ir padaliniams / ugdomos kompetencijos (sudaryta autorių)

\begin{tabular}{|c|c|c|c|}
\hline Rengimo reikalavimai / kompetencijos & $\begin{array}{c}\text { Pès- } \\
\text { tinin- } \\
\text { kams }\end{array}$ & $\begin{array}{l}\text { Kitų } \\
\text { padalinių } \\
\text { kariams }\end{array}$ & Šaltinis \\
\hline Greitai reaguoti ị pasirodžiusị priešą ir taikliai šaudyti & $\mathrm{X}$ & & $\begin{array}{l}\text { Šaudymo vadovas, } 2020, \\
\text { p. } 1-1,1004,1 \text { punktas }\end{array}$ \\
\hline Taikliai šaudyti & & $\mathrm{X}$ & $\begin{array}{l}\text { Šaudymo vadovas, } 2020, \\
\text { p. } 1-1,1004,2 \text { punktas }\end{array}$ \\
\hline Tik individualiai & & $\mathrm{X}$ & $\begin{array}{l}\text { Šaudymo vadovas, } 2020 \text {, } \\
\text { p. } 1-1,1004,2 \text { punktas }\end{array}$ \\
\hline Individualiai ir padalinio sudètyje & $\mathrm{X}$ & & $\begin{array}{l}\text { Papildyta autoriu, } \\
\text { dedukciniu būdu } \\
\text { analizuojant } \\
\text { reikalavimus }\end{array}$ \\
\hline $\begin{array}{l}\text { Nukauti ar sulaikyti priešą per savo ginklo šaudymo } \\
\text { nuotoli }\end{array}$ & $\mathrm{X}$ & & $\begin{array}{l}\text { Šaudymo vadovas, } 2020, \\
\text { p. } 1-1,1004,1 \text { punktas }\end{array}$ \\
\hline Nukauti ar sulaikyti priešą artimajame mūšyje & $\mathrm{X}$ & & $\begin{array}{l}\text { Šaudymo vadovas, } 2020, \\
\text { p. } 1-1,1004,1 \text { punktas }\end{array}$ \\
\hline $\begin{array}{l}\text { Šaudyti iš ịvairiu šaudymo padèčių, judant iš už } \\
\text { priedangos, bet kokiomis sąlygomis }\end{array}$ & $\mathrm{X}$ & & $\begin{array}{l}\text { Šaudymo vadovas, } 2020, \\
\text { p. } 1-1,1004,1 \text { punktas }\end{array}$ \\
\hline $\begin{array}{l}\text { Gebèti nukauti ar sulaikyti priešą gynyboje ir } \\
\text { puolime iki } 400 \text { m šaudymo nuotoliu (išskyrus } \\
\text { kulkosvaidininkus) }\end{array}$ & $\mathrm{X}$ & & $\begin{array}{c}\text { Šaudymo vadovas, } 2020, \\
\text { p. } 1-1,1004,1 \text { punktas }\end{array}$ \\
\hline $\begin{array}{l}\text { Pirmiausia gynyboje, iki } 400 \mathrm{~m} \text { šaudymo nuotoliu } \\
\text { (išskyrus kulkosvaidininkus) }\end{array}$ & & $\mathrm{X}$ & $\begin{array}{l}\text { Šaudymo vadovas, } 2020, \\
\text { p. } 1-1,1004,1 \text { punktas }\end{array}$ \\
\hline
\end{tabular}

Atkreiptinas dėmesys, kad pėstininkai turi gebėti veikti puolimo ir gynybos veiksmu metu, o kiti kariai - pirmiausia gynyboje. Žodis pirmiausia suponuoja, kad gynyba yra prioritetas, bet vèliau kariai turi būti mokomi šaudyti ir pagal kitus taktinius scenarijus. Apibendrinant galima teigti, kad karių parengimas skirtingoms ìvardytoms operacijoms - gynybai, puolimui - nèra tinkamas, nes karinis rengimas planuojamas remiantis kariniam vienetui iškeltu uždaviniu ir aukštesniojo vado (karinio vieneto) uždavinio esminių užduočių sąrašu (UEUS) (Kolektyvinio rengimo vadovas, 2019).

Šaulių rengimo sistema ir karių skirstymas i pėstininkus ir kitų padalinių karius nesudaro prielaidų tinkamai jų parengti naudoti pistoletą savigynai, nes kitų padalinių kariams nekeliamas reikalavimas mokèti greitai ir artimajame mūšyje naudoti ginklą. „Ginkluotas užpuolikas, turintis rankoje peilį, $10 \mathrm{~m}$ atstumu nekelia pavojaus pareigūnui, tačiau užtenka tik 2 sek., kad jis staigiais judesiai priartètu ir pakeistų saugią situaciją ị mirtiną" (Petersson et al., 2017). Kiekvienas karys, kaip 
ir civilis, turi prigimtinę teisę gintis (Lietuvos Respublikos Konstitucija, 1992), o „kovinių ginklų, specialiųjų priemonių ir kitos karinès jègos naudojimo taisyklès neriboja prigimtinès asmenų teisès naudoti kovinius ginklus, specialiąsias priemones ir kitą karinę jègą, kai tai yra naudojama savigynos tikslais“" (Krašto apsaugos sistemos organizavimo ir karo tarnybos istatymas, 2008). Lietuvos Respublikos baudžiamojo kodekso V skyriaus „Baudžiamają atsakomybę šalinančios aplinkybès“ 28 straipsnis reglamentuoja asmenų teisę i būtinają gintị. Jame aiškiai pasakyta, kad ji igyvendinama tada, kai nèra peržengtos būtinosios ginties ribos. „Būtinosios ginties ribų peržengimas yra tuo atveju, kai tiesiogine tyčia nužudoma arba sunkiai sutrikdoma sveikata, jeigu gynyba aiškiai neatitiko kèsinimosi pobūdžio ir pavojingumo. Būtinosios ginties ribų peržengimu nelaikoma dèl didelio sumišimo ar išgąsčio, kurị sukèlè pavojingas kèsinimasis, arba ginantis nuo įsibrovimo ị būstą padaryta veika“ (Lietuvos Respublikos baudžiamasis kodeksas, 2000). Apibendrinus išvardytas teises ir galimus apribojimus, darytina išvada, kad kariai gali (turi teisę) naudoti tarnybini ginklą savigynai, tik jų veiksmai turi būti gynybiniai ir atitikti kèsinimosi pobūdị ir pavojingumą, kaip to reikalauja Lietuvos Respublikos baudžiamasis kodeksas. Lietuvos kariuomenè, suteikdama kariui teisę disponuoti šaunamuoju ginklu, turi ji tam ir parengti. Karys turi gebėti greitai reaguoti, nes kova vyks artimajame mūšyje. 1 lentelèje matyti, kad kitų padalinių kariai tokių kompetencijų neturetų igyti, o tai nesudaro galimybių jiems net savo teisès ị savigyną igyvendinti.

Iprastai Lietuvos kariuomenès daliniuose dienos tarnyba atliekama apginklavus karius pistoletais ir retais atvejais - tik ten, kur reikia (nedetalizuojama), - automatiniais šautuvais. Tam yra kelios priežastys: dienos tarnyba vyksta pastatuose (uždarose erdvėse), o pistoletas yra patogesnis ginklas (trumpesnis vamzdis). Ar „Šaudymo vadovo“ leidinyje aprašyta šaulio rengimo sistema sudaro sąlygas tinkamai parengti péstininkų ir kitų padalinių karius greitai ir artimajame mūšyje naudoti kovinį ginklą - pistoletą? Šaulio rengimo šaudyti iš pistoleto sistemą sudaro GVT ir 4 etapai (žr. 1 pav.): „1 etapas - pataikymų sklaidos dydžio nustatymas ir ginklų įsaudymas, 2 etapas - pradinis ir aukštesniojo lygio šaudymas, 3 etapas - kasmetiniai šaudymo iš individualaus ir papildomo ginklo testai, 4 etapas - perejimas prie kovinio šaudymo taktikos pratybų“" (Šaudymo vadovas, 2020, p. 5-1). 


\section{LK ŠAULIŲ RENGIMO SISTEMA}

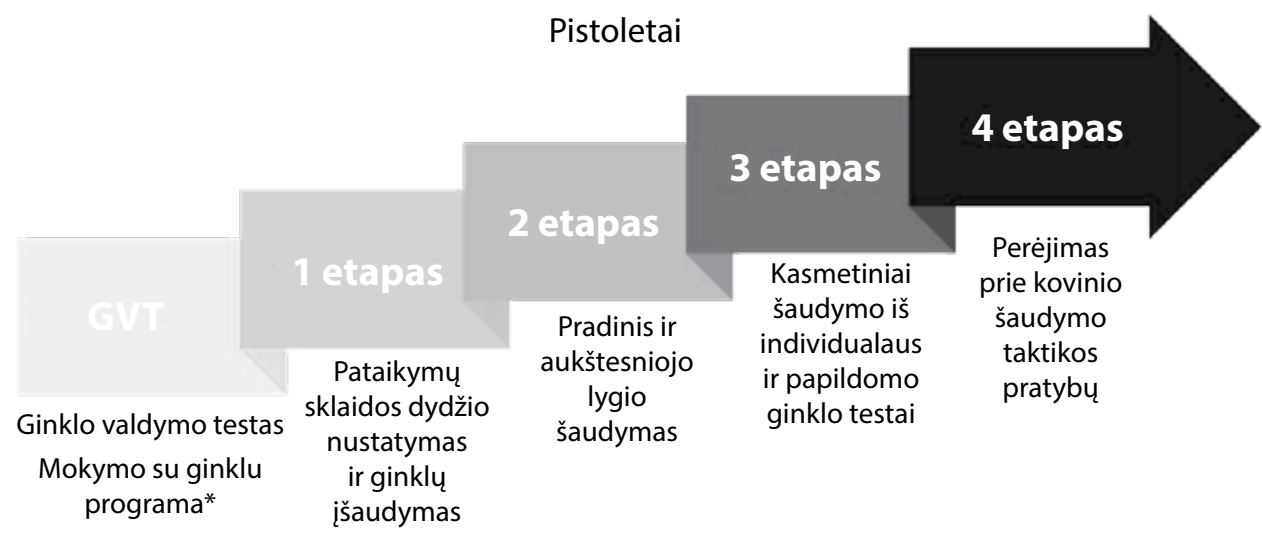

1 pav. Lietuvos kariuomenės šaulių rengimo sistema (pistoletai) (sukurta autorių)

Siekiant tinkamai parengti pėstininkus ir kitų padalinių karius pagal tai, kaip juos skirsto „Šaudymo vadovas“, būtina dar atsižvelgti ị priskirtus ginklus - individualus ar papildomas ginklas - ir ị laiką - pirmi tarnybos metai ar paskesni. Nuo kiekvieno šio kriterijaus priklauso šaulio rengimo reikalavimai. Atitinkamai, atsižvelgiant ị konkrečias kario pareigas, jam priskirtas ginklas (gali būti priskirti ir keli ginklai) laikomas individualiu kario ginklu, o kario profesionalumas vertinamas kasmetinių šaudymo iš individualaus ginklo testų (KŠIGT) metu. Ginklas, kuris nèra priskirtas kariui, bet yra jo padalinyje, yra papildomas, todèl ir karys turi būti ịver-

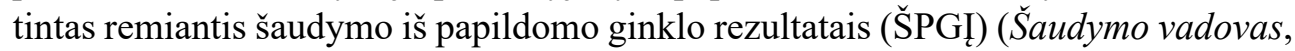
2020, p. 1-1). Toks ginklų suskirstymas leidžia ịteisinti karių šaudymą iš nepriskirtų ginklų, kad mūšio (ginkluoto susiremimo) metu jis prireikus galètų naudoti bet kurị padalinyje esanti ginklą. Vertinant, ar „Šaudymo vadove“ nurodyta rengimo seka pavyksta parengti karius greitai ir artimajame mūšyje naudoti ginklą, buvo tiriamas jų rengimas iki kasmetinių šaudymo iš pistoleto testų. Atsakant ị šį klausimą, turi būti detalizuota (apibrèžta) sąvokų ,greitas ginklo naudojimas (šaudymas)“ ir „,artimasis mūšis" praktinè prasmè (standartas). Nagrinejjant pirmają sąvoką, kurioje yra žodis „greitas“, atkreiptinas dèmesys, jog leidinyje parašyta, kad karys turi mokèti šaudyti staigiuoju būdu (sąvoka "staigusis šaudymas") ir greitašauda (Šaudymo vadovas, 2020, p. 1-5). Sąvokų apibrěžimai ir standartai pateikti 2 lentelejje.

Karys, atlikdamas KŠIGT:

- turi pataikyti ị taikinį Nr. 11 iš $15 \mathrm{~m}$ atstumo stovẻdamas arba priklaupęs, taikliai iššauti per 3 sek. iš parengties pozicijos (pistoletą laikydamas prieš šūvị rankose); atlikti 2-ają pratimo dalį tomis pačiomis sąlygomis, bet papildomai užsidejjęs dujokaukę ir tik iš stovimos padèties, iššauti taiklų šūvị per 5 sek.;

- kitų padalinių kariai neatlieka KŠIGT, jie vykdo sutrumpinto (be 2-osios dalies) testo (ŠPGİ) užduotis;

- turi pataikyti ị taikinị Nr. 11 iš 15 m stovèdamas ir užsidèjęs dujokaukę, 
taiklų šūvị iššauti per 5 sek. iš parengties pozicijos (pistoletą laikydamas prieš šūvị rankose);

- $25 \mathrm{~m}$ atstumu šaulys iš padecčiu ,stovint“, vèliau - ,priklaupus“ turi pataikyti ị taikinį Nr. 114 kartus per 8 sek.;

- šaulys, pamatęs taikinį, turi per 10 sek. nubėgti $5 \mathrm{~m}$, išsitraukti pistoletą, ji užtaisyti ir atsistoti ị parengties padèti ,stovint“;

- šaulys turi gebèti iššauti per 4 sek. 4 šūvius ir pataikyti ị taikinį, esantị už $20 \mathrm{~m}$, priklaupęs, prieš tai ginklą išsitraukęs ir užtaisęs (šie veiksmai neįeina ị 4 sek. limitą).

2 lentelè. Reikalavimai šauliams ir padaliniams / ugdomos kompetencijos (sudaryta autorių)

\begin{tabular}{|c|c|c|}
\hline Sąvoka & Apibrèžimas & Standartas KŠIGT metu (Šaudymo vadovas, 2020, p. 18) \\
\hline \multirow[t]{3}{*}{$\begin{array}{l}\text { Staigusis } \\
\text { šaudymas }\end{array}$} & \multirow{3}{*}{$\begin{array}{l}\text { Tai šaudymas, kai } \\
\text { taikinio rodymo laikas } \\
\text { yra ribotas. Karys turi } \\
\text { iššauti vieną kartą i } \\
\text { kiekvieną pasirodžiusị } \\
\text { taikini. Staigusis } \\
\text { šaudymas pradedamas } \\
\text { nuo } 2 \text { etapo. } \\
\text { (Šaudymo vadovas, } \\
\text { 2020, p. 1-5) }\end{array}$} & $\begin{array}{l}\text { Parengtis: šaulys stovi parengties pozicijoje (be dujokaukès). } \\
\text { Atstumas: } 15 \mathrm{~m} \\
\text { Pozicija: stovint, priklaupus } \\
\text { Taikinys: taikinys Nr. } 11 \text { (1145 x } 455 \mathrm{~mm}) \\
\text { Laikas: taikinio parodymo } 3 \mathrm{sek} .\end{array}$ \\
\hline & & $\begin{array}{l}\text { Parengtis: šaulys stovi parengties pozicijoje (su dujokauke). } \\
\text { Atstumas: } 15 \mathrm{~m} \\
\text { Pozicija: stovint } \\
\text { Taikinys: taikinys Nr. } 11(1145 \mathrm{x} 455 \mathrm{~mm}) \\
\text { Laikas: taikinio parodymo } 5 \text { sek. }\end{array}$ \\
\hline & & $\begin{array}{l}\text { Parengtis: šaulys stovi parengties pozicijoje (be dujokaukės), } \\
\text { pistoletas užtaisytas, keitiklis nustatytas ị saugos padètị (jei yra). } \\
\text { Atstumas: } 25 \mathrm{~m} \\
\text { Pozicija: stovint, priklaupus } \\
\text { Taikinys: du taikiniai Nr. } 11 \text { (1145 x } 455 \mathrm{~mm} \text { ) } \\
\text { Laikas: taikinių parodymo laikas } 8 \text { sek. } \\
\text { Standartas: „Pirmo parodymo metu ị kairiji taikinị iššaunama } 4 \\
\text { kartus iš padèties „stovint““, po to užimama padètis „priklaupus“ } \\
\text { ir antro parodymo metu iššaunama } 4 \text { kartus ị dešiniji taikinị.“ }\end{array}$ \\
\hline $\begin{array}{l}\text { Greita- } \\
\text { šauda }\end{array}$ & $\begin{array}{c}\text { Tai šaudymas, kai } \\
\text { taikinio rodymo laikas } \\
\text { yra ribotas. Karys turi } \\
\text { iššauti ị pasirodžiusị } \\
\text { taikinị nurodytą kartų } \\
\text { skaičių. Taikinys } \\
\text { nukrenta pasibaigus } \\
\text { rodymo laikui, } \\
\text { pataikymai fiksuojami. } \\
\text { (Šaudymo vadovas, } \\
\text { 2020, p. } 1-5 \text { ) }\end{array}$ & $\begin{array}{l}\text { Parengtis: šaulys stovi parengties pozicijoje (be dujokaukès) } \\
25 \mathrm{~m} \text { atstumu nuo taikinio. Pistoletas neužtaisytas, detuvè } \\
\text { įstatyta, pistoletas užsegtame dèkle, keitiklis nustatytas } \\
\text { saugiklio padètị (jei yra). Pastebèjęs taikinị šaulys juda ị } 20 \mathrm{~m} \\
\text { šaudymo poziciją, išsitraukia pistoletą, užtaiso ji ir atsistoja ị } \\
\text { parengties padètį. } \\
\text { Atstumas: } 20 \mathrm{~m} \\
\text { Pozicija: priklaupus } \\
\text { Taikinys: du taikiniai Nr. } 11 \text { (1145 x } 455 \mathrm{~mm}) \\
\text { Laikas: taikinio parodymo } 4 \text { sek. du kartus } \\
\text { Standartas: du taikiniai, galima šauti ne daugiau kaip } 4 \text { kartus ị } \\
\text { vieną taikini jam pakilus. Iš viso } 8 \text { šūviai. }\end{array}$ \\
\hline
\end{tabular}


Mokslinès dedukcijos būdu nustatyti šaulių igūdžiai šaudant iš pistoleto, kurie leistų kariui būti efektyviam ir greitai reaguoti į grèsmę, apsiginti ir apginti kitus ar turtą uždarose patalpose (vietovèse), naudoti ginklą vykdant kitas užduotis: greitai ji išsitraukti ir užtaisyti, šaudyti greitašauda (iššauti daugiau nei vieną šūvị) ị taikinị iš ịvairių šaudymo padèčių, greitai pakeisti dètuves, prireikus pašalinti strigimą, šaudyti judant, keičiant ar pasirenkant taikinius, taip pat iš įvairių pozicijų ir išnaudojant priedangas, i judančius taikinius. Palyginus rekomenduotinas kompetencijas su KŠIGT ir ŠPGI sudedamosiomis dalimis galima apibendrinti, kad kariai nèra mokomi ir testuojami:

- per nustatytą laiką išsitraukti pistoletą, užtaisyti jị ir iššauti (3 dalyje atskirai 5 m nubėgti ir išsitraukti ginklą, jam užtaisyti skiriama 10 sek., ir tada reikia laukti pasirodančių taikinių);

- greitai keisti dètuves (pratimo taisyklès nereikalauja susidèti dètuvių į dètuvių dèklus ir pratimo metu nereikia greitai jų keisti);

- ginklui užsikirtus, šalinti priežastị (pratimo taisyklèse rašoma: ,ginklui užsikirtus papildomai laiko neskiriama“" (ک̌audymo vadovas, 2020, p. 5-17), tačiau ginklo užsikirtimo atvejai šaudant mokomaisiais šoviniais neimituojami);

- šaudyti iki $15 \mathrm{~m}$ atstumu;

- šaudyti, kai dẻkle yra užtaisytas ginklas.

Karys, išlaikęs KŠIGT arba ŠPGIt, gali ir toliau tobulinti savo šaudymo iš pistoleto ịgūdžius, jei karinio vieneto vadas planuoja rengti kovinio šaudymo iš pistoleto pratybas ,pastate - šaudykloje“, perejus prie kovinio šaudymo taktikos pratybų (4 šaudymo etapas) ir atliekant artimojo mūšio pratimus (AMP). Dažniausiai šie pratimai būna įtraukti ị péstininkų, bet neịtraukti ị kitų padalinių karių rengimo programą, nors teoriškai tiek pėstininkų, tiek kitų padalinių karių rengimas gali būti vienodas, nes tai nustato dalinio vadas.

Atsižvelgiant $i ̣$ atskleistus aspektus, yra prielaidų teigti, kad Lietuvos kariuomenès šaulių rengimo sistema yra nenuosekliai sudarytos mokymo programos pavyzdys, kur pėstininkams ir kitų padalinių kariams nustatyti šaudymo reikalavimai yra taisytini su sąlyga, kad karių rengimo prioritetas turètų būti jų gebẻjimas naudoti ginklą nedideliu nuotoliu (iki $15 \mathrm{~m}$ ).

Lietuvos kariuomenès šaulių rengimo sistemos dalies - mokymo šaudyti iš pistoleto - lyginimas su kitų šalių šaudymo iš pistoletų mokymo ir praktinio naudojimo patirtimi

Lietuvos kariuomenès šaulių rengimo sistema - tai mokymo programa, turinti savo tikslus, metodus ir priemones jiems pasiekti. Kiekvienos mokymo programos turinys labai priklauso nuo jos tikslo. Siekiant atskleisti kariu igyjamas kompetencijas, lyginamos Lietuvos ir JAV kariuomenių sausumos pajėgu (angl. Army) šaulio rengimo sistemos ir strategijos, aptariami jų panašumai ir skirtumai. Atliekant dedukcinę kokybinę turinio analizę, pasirinkti kriterijai, kurie vèliau buvo 
analizuojami taikant manifestinę analizę (Žydžiūnaitè ir Sabaliauskas, 2017). Gauti rezultatai gretinami su Lietuvos ir užsienio autorių publikacijose įvardytomis pistoletų praktinio naudojimo tendencijomis.

JAV kariuomenès sausumos pajègos, pakeitusios rengimo naudoti individualius ginklus ir kvalifikacijos kèlimo strategiją, mokymą organizuoja pagal šaudymo iš pistoleto strategijos (kuri yra minètos strategijos dalis - aut. pastaba) šešis etapus (žr. 2 pav.): 1 - pradinis taiklaus šaudymo rengimas ir vertinimas (angl. preliminary marksmanship instruction and evaluation), 2 - pradinis kovinio šaudymo imitavimas (angl. preliminary life-fire simulation), 3 - pratimai (angl. drills), 4 - šaudymo pagrindai (sklaida) (angl. basics), 5 - praktika (angl. practice), 6 - kvalifikacija (angl. qualification) (Headquarters, 2019, p. D-1). Paskutiniame etape kariai yra testuojami ir jiems suteikiama kvalifikacija, kaip ir pagal Lietuvos kariuomenès šaulio rengimo sistemos dalies - mokymo šaudyti iš pistoleto - reikalavimus, t. y. laikomi KŠSIGT ar ŠPGĮ. Sistema ir strategija lyginamos atitinkamai iki 3 ir 6 etapų įskaitytinai, nes būtent šiuose etapuose Lietuvos ir JAV kariai igyja reikalaujamą kvalifikaciją, kad galètų tinkamai naudoti pistoletą.

\section{ŠAUDYMO IŠ PISTOLETO RENGIMO STRATEGIJA}

(pistol training strategy)

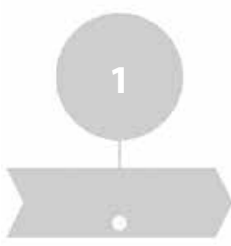

Pradinis taiklaus šaudymo rengimas ir vertinimas

(angl. preliminary marksmanship instruction and evaluation)

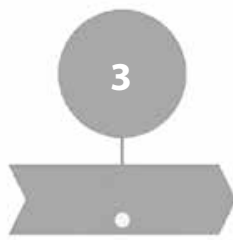
šaudymo simuliavimas/ imitavimas

(angl. preliminary life-fire simulation)
Pratimai

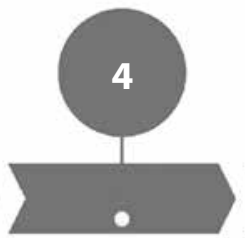

Šaudymo pagrindai (sklaida)

(angl. drills)

(angl. basics)

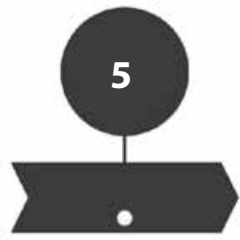

Kvalifikacija

(angl. qualification)

2 pav. JAV sausumos pajęgų šaudymo iš pistoleto rengimo strategija (sudaryta autorių)

Analizuojant minètą sistemą ir strategiją matyti reikšmingas GVT ir JAV strategijos skirtumas parengiamajame mokymo šaudyti etape „Pradinis taiklaus šaudymo rengimas ir vertinimas“. JAV karių rengimas organizuojamas nuosekliai, turint individualiujų užduočių standartus ir kartu aiškią tvarką, kada karys turi išlaikyti teorijos ir ịgūdžių testus. Lietuvos kariuomenès šaulių rengimo sistemos svarbiausias yra 1 etapas - GVT laikymas, nes pabrěžiama, kad karys, laikantis pirmą kartą GVT, turi išeiti mokymo programą. Vykdant praktinį karių rengimą dažniausiai pasitaikanti klaida - kad reikalaujama ne to, ko buvo mokoma. Lyginant sistemą 
ir strategiją, atsiskleidžia ir daugiau skirtumų: kariui išlaikius GVT ir pirmą kartą šaudant, būtina pasiekti $180 \mathrm{~mm}$ sklaidą $10 \mathrm{~m}$ atstumu, karys mokosi šaudydamas, jokių treniruočių, kaip užimti atitinkamas pozicijas, kaip taikytis, keisti dètuves ir tobulinti kitus įgūdžius, reglamentuota nèra.

JAV šaudymo iš pistoleto rengimo strategijoje pastebimas reikšmingas pokytis, susijęs su karių mokymo metodika, nes vykdomas privalomas individualusis rengimas, karys turi atitikti visus standartus demonstruodamas ịgūdžius, o jo teorijos testo rezultatas turi būti 80 proc. ir daugiau. Reikalavimai turi būti ịvykdyti ne anksčiau kaip prieš 6 savaitès iki kovinio šaudymo.

Lietuvos kariuomenès šaulių rengimo sistema neišnaudoja papildomų treniravimo priemoniu kariams rengti, bet tik atkreipia dèmesi i kovinị šaudymą. „Šaudymo vadove" numatyta galimybė naudoti lazerinị šaulių treniruoklị (LŠT), tačiau pabrèžiama, kad jis skirtas blogiau šaudantiems kariams (kriterijus „blogiau“ nèra apibūdintas) treniruoti. „Šaudymo vadovai skatinami optimaliai išnaudoti šią įrangą visur, kur ji yra instaliuota“ (Šaudymo vadovas, 2020, p. 1-5). JAV kariai mokomi šaudyti iš pistoleto naudojant mokomuosius šovinius, naktinio matymo įrangą, virtualiosios realybės imitatorius (Headquarters, 2019), o kur jų nèra - lazerinius šaulių treniruoklius, kaip ir Lietuvoje. Pačių mokymo priemonių naudojimas nesudaro prielaidų, kad kariai bus tikrai kokybiškai parengti, jei jos nèra parenkamos tinkamai, bet JAV strategijoje dèl naudojamų priemonių tikslingumo nekyla jokių abejonių. Galima paminèti pavyzdị, kai mokomieji šoviniai naudojami siekiant pratinti karius šalinti ginklo užsikirtimus, o imitavimo sistemas - treniruojant karių igūdžius prieš kovinị šaudymą, nes tai neabejotinai tik gerina rengimo kokybę.

Sudarant šaudymo programą labai svarbus yra tikslas (užduotis, sąlygos, standartai). Ir tik išmanant šiuos standartus galima pasakyti, ar programa atitinka keliamus reikalavimus. Pasikeitus operatyvinei aplinkai, oponentų taktikai, būtina keisti mokymo tikslą ir rengimo programą. Siekiant atskleisti šaulių rengimo sistemos aspektus buvo remtasi publikacijomis, kuriose nagrinėjami policijos pareigūnu kovinio ginklo panaudojimo atvejai (Petersson et al., 2017). Šie tyrejjai, atlikę 112 Švedijos policijos pareigūnų apklausą, teigia, kad Švedijos policija 42 proc. atvejų pistoletus naudojo iki $3 \mathrm{~m}, 23$ proc. - iki $7 \mathrm{~m}, 18$ proc. - nuo 7 iki $15 \mathrm{~m}, 17$ proc. daugiau kaip $15 \mathrm{~m}$ atstumu. JAV policijos pareigūnai, atlikdami savo pareigas, naudojo pistoletą iki 13,71 m (15 jardų) atstumu, skirtingų tyrimų duomenimis, 94-96 proc. atvejų (Avis, 2018; Bratton, 2015).

Šaulių rengimo sistemos kovinio šaudymo pratimai iš pistoleto iki 3 etapo imtinai, ruošiant laikyti KŠIGT ar ŠPGİ ir jų metu, atliekami šaudant $10-25$ m atstumu ị stacionarius taikinius. Atlikdami tam tikrus pratimus, šauliai turi per nustatytą laiką nukauti du vienu metu pasirodžiusius taikinius. O JAV kariai per treniruotes ir kvalifikacijos testą šaudo skirtingu atstumu, pvz., iki 7, 10, 12,5, 16,5, 23, 27 ir $31 \mathrm{~m}$ (Headquarters, 2019, p. D-1). Taikiniai taip pat yra stacionarūs, nes nejuda, tačiau atkreiptinas dėmesys, kad Lietuvos kariai šaudo 10, 15, 20, 25 m atstumu, o JAV kariai treniruojami šaudyti nevienodais intervalais iš didesnio ar mažesnio 
atstumo ir, kai šaudoma ị du vienu metu pakilusius taikinius, būna išsidèstę skirtingu atstumu, kas, tikètina, leidžia jiems geriau pasirengti įvairiems ateities ginklo panaudojimo scenarijams.

Lietuvos karių rengimas šaudyti iš pistoleto vyksta dienos metu. Kariai, kurie laiko KŠIGT, atlieka šaudymo užduotis ir imituojamomis ChBRB sąlygomis - šaudo dèvėdami dujokaukes. JAV kariai taip pat treniruojami šaudyti užsimovę dujokaukes, tačiau jie dar papildomai šaudo ir riboto matomumo sąlygomis - tamsoje naudodami naktinio matymo prietaisus, kas leidžia JAV karius parengti efektyviai naudoti ginklą ne tik dieną, bet ir naktį. Policijos pareigūnai, kariai, be abejo, gali naudoti ginklą tiek tamsiu, tiek šviesiu paros metu. $2015 \mathrm{~m}$. Lietuvos policijos pareigūnai 35 proc. visų atvejų buvo priversti naudoti ginklą riboto matomumo sąlygomis, Švedijos pareigūnai - net 60 proc. tokių atvejų, policijos pareigūnai 6 proc. atvejų naudojosi žibintuvèliais (Petersson et al., 2017). JAV policijos pareigūnų ginklų panaudojimo statistika rodo, kad daugiau nei pusè atvejų tai buvo padaryta riboto matomumo sąlygomis. Kaip teigia Aveni (2003), Niujorko policijos departamente ginklo panaudojimo atvejai riboto matomumo sąlygomis sudare 77 proc., Majamio policijos departamente - 62 proc., Baltimorès policijos departamente 59 proc. Atsižvelgiant ị JAV karių rengimo patirtị ir policijos surinktus pistoleto naudojimo riboto matomumo sąlygomis duomenis, galima daryti išvadą, kad Lietuvos kariai nèra rengiami šaudyti iš pistoleto riboto matomumo sąlygomis.

Pirmoje publikacijos dalyje autoriai apibendrino, kad kariai nèra rengiami šaudyti greitai ir artimojo mūšio sąlygomis ir tik kariai, kuriems sudarytos galimybės dalyvauti 4-ajame šaulio rengimo sistemos etape „Perẻjimas prie kovinio šaudymo pratybų“, yra rengiami artimajam mūšiui, atliekant artimojo mūšio pratimus. Dedukcijos būdu buvo pateiktos būtinosios kompetencijos, kad rengiami kariai išnaudotu pistoleto teikiamas galimybes artimojo mūšio metu, tačiau policijos pareigūnų patirtis atskleidè papildomų aspektų. Kaip teigia Bratton (2015), policijos pareigūnai 63 proc. ginklo panaudojimo atvejų šaudė pistoletą laikydami abiem rankomis (pagrindinis pistoleto laikymo būdas, stabiliausias - aut. pastaba), 56 proc. atvejų - iš pozicijos ,stovint“", 33 proc. pareigūnų šaudè judedami ir net 11 proc. - sèdèdami, nè vienam pareigūnui nereikèjo keisti dètuvès, nes daugiausiai vieno šaudymo metu buvo iššauta 12 šūvių. Tyrèjai (Petersson et al., 2017) pateikia pistoleto naudojimo greičio duomenis. Autorių teigimu, 39 proc. visų ginklo panaudojimo atvejų pirmam šūviui iššauti turèjo iki 3 sek., 27 proc. policijos pareigūnų panaudojo pistoletą per 3-10 sek. JAV kariai rengiami šaudyti nuo 7 iki $31 \mathrm{~m}$ atstumu, vienam taikiniui sunaikinti skiriamos 3 sek., dviem taikiniams -5 sek., taip pat treniruojamas ir karių gebejjimas šaudyti taikant taktinio naikinimo prioritetą (angl. tactical priority) (artimesnis taikinys naikinamas pirmas - aut. pastaba). Apibendrinant šią Lietuvos kariuomenès šaulių rengimo sistemos dalị (šaudymo pratimus), JAV karių rengimo ypatumus ir policijos pareigūnų praktinę patirtį, galima teigti, kad šaulio rengimo sistema neatitinka ne tik sajungininkų rengimo metodikos, bet ir policijos pareigūnų pistoleto naudojimo praktinių aspektų. 
Darytina pagrindinè išvada, kad, kaip ir teigiama „Šaudymo vadove“, pèstininkai turi būti rengiami ,greitai reaguoti ị priešo pasirodymą ir taikliai šaudyti<...>", ,nukauti ar sulaikyti priešą artimajame mūšyje“" (Šaudymo vadovas, 2020, p. 1-1), kas, straipsnio autorių nuomone, yra būtinos kiekvienam kariui (ne tik pèstininkui) kompetencijos, juos mokant tinkamai naudoti kovinį ginklą, pirmiausia - savigynos tikslais, vykdant tarnybines užduotis ar kaunantis mūšyje. Šaulio rengimo šaudyti iš pistoleto sistema turètų būti peržiūrèta ir pakeista taip, kad kiekvienas karys būtų išmokytas naudoti šį ginklą greitai, taip pat ir artimojoje kovoje. Prioritetą teikiant šaulio rengimui, būtina karius parengti naudoti ginklą iki $15 \mathrm{~m}$ atstumu, nepamirštant riboto matomumo sąlygų, kai naudojamas žibintuvèlis ir (ar) naktinio matymo prietaisai, šaudymo imituojamomis ChBRB sąlygomis, šaudymo ị taikinius $25-30 \mathrm{~m}$ atstumu, šaudymo judant $\mathfrak{i}$ stacionarius ir judančius taikinius iš įvairių pozicijų.

\section{Šaulių rengimas prieš kovinị šaudymą iš pistoleto ir šaulių rengimo sistemos tobulinimo gairès}

Kariuomeneje paplitusi praktika, kad kario rengimas šaudyti iš pistoleto pradedamas nuo supažindinimo su ginklo valdymo testu (toliau - GVT). Paprastai atspausdinami GVT lapai, kariui parodomos manipuliacijos su ginklu, jis porą kartu pakartoja kiekvieną iš parodytų elementų (veiksmų su ginklu), perskaito GVT. Mokymas jau ịvyko, belieka, nepadarius su saugumu susijusių klaidų ir laikantis GVT standarto reikalavimų, išlaikyti GVT. „Šaudymo vadove“ pateikti kitokie karių mokymo reikalavimai, nes GVT turi būti laikomas mokymų metu, „iš karto po to, kai buvo išdèstytos visos ginklų valdymo paskaitos“. „Kariai, pirmą kartą laikantys GVT, turi būti išèję visą mokymo su ginklu programą (pagal kovinio rengimo nuostatas turi būti organizuotas mokymas (pradinis rengimas, ịgūdžių formavimas, igūdžių įtvirtinimas)." Be to, yra reikalavimas, kad kariai turi išlaikyti GVT kartą per metus prieš pirmaji ̌̌audymą. Kariui, pažeidusiam saugaus elgesio su ginklu reikalavimus, GVT rezultatai anuliuojami (nebegalioja), ir karys turi būti mokomas iš naujo, o vèliau testuojamas (Šaudymo vadovas, 2020). „Kariai turi būti išeję visą mokymo su ginklu programą<...>" (Šaudymo vadovas, 2020, p. 1-2). Kas sudaro šią programą? Ir kodèl praktika kariniuose vienetuose neatitinka „Šaudymo vadove“ išdèstytų reikalavimų? Ieškodami „Lietuvos karinių pajègų rengimo doktrinoje (D-LK-07)“ programos sąvokos apibūdinimo, perskaitysime: ,paprastai kursui parengiama viena mokymo (užsièmimų) programa, bet gali būti išimčių“, „karinès mokymo ir / ar rengimo ịstaigos (institucijos) tam tikro kurso mokymo programa yra dokumentas<...>“" (Šaudymo vadovas, 2020, p. 4-9).

Atsižvelgiant ị tai, kad karinių vienetų ginklai yra skirtingi, pirmą kartą rengimas naudoti ginklą pagal „programą“ turètų vykti tame pačiame kariniame vienete, nes neįmanoma tam numatyti ir parengti visų ginklų bazinio karinio mokymo metu. Daliniuose ir padaliniuose karinis rengimas vykdomas vadovaujantis užduočių stan- 
dartais, kario, šaulio mokymas naudoti ginklus yra individualiojo rengimo objektas, todèl pats rengimas turètų būti igyvendinamas remiantis individualių užduočiu atlikimo standartais (IUAS). „Individualiajam rengimui skirtuose leidiniuose yra išvardytos užduotys, jų atlikimo sąlygos ir standartai (užduoties dalys ir vykdymo priemonès, t. y. vykdymo eiliškumas ir atlikimo vertinimas)“" (Lietuvos kariniu pajegu rengimo doktrina, 2013, p. 2P-1). Atsakant ị anksčiau iškeltus klausimus galima daryti išvadą, jog „Šaudymo vadove“ pateiktas nurodymas, kad kariai, pirmą kartą rengiami naudoti ginklą, turi būti išèję rengimo programą, praktiškai mokant šaudyti iš pistoleto, neigyvendinamas, nes nèra tam numatyto mokymo IUAS.

Lietuvos kariuomenès Sausumos pajègų naudojimosi ginklais rengimo spragas galimai bandyta pašalinti išleidžiant $2017 \mathrm{~m}$. sausio $27 \mathrm{~d}$. ịsakymą Nr. V-48 „Dèl Lietuvos kariuomenès Sausumos pajègų vado 2014 m. gegužès $23 \mathrm{~d}$. ịsakymo Nr. V-293 „Dèl Sausumos pajègų kovinio rengimo standartinių veiklos procedūru tvirtinimo" papildymo", kuriame reglamentuota karių rengimo eiga pateikiant loginio nuoseklumo schemą (minimalūs reikalavimai) ir mokymo naudoti ginklus turinys pagal privalomų užsièmimų su ginklais sąrašą. Loginio nuoseklumo schemoje įtvirtintas reikalavimas, kad, priskyrus ginklą naujam kariui, būtina jam organizuoti paskaitas ir pratybas pagal ginklo tipą. Išèję mokymo programą kariai turi išlaikyti GVT, prieš tai išlaikę ir teorijos žinių testą. Tokia pat vertinimo tvarka yra taikoma ir JAV sausumos pajègose: ,padaliniai parengs testą raštu, ịvertinantị funkcinị ginklo, amunicijos ir kritinių igūdžių aspektus, išdèstytus leidinyje TC 3-23.35. Vèliau kariai turi sèkmingai atlikti nurodytas užduotis<... > (Headquarters, 2019, p. D-3).

Taigi kario rengimas šaudyti iš kovinio ginklo vykdomas tikrinant jo kognityvinius ir psichomotorinius gebejimus. Vèliau, remiantis Lietuvos kariuomenès Sausumos pajėgų vado nustatyta tvarka, karys (5-ajame loginio nuoseklumo schemos etape) mokomas taikyti taiklaus šaudymo principus, jei yra galimybė, ir rengiamas lazeriniame treniruoklyje, supažindinamas su bataliono vado įsakymu dėl saugaus elgesio taisyklių laikymosi (pasirašytinai) ir tik tada gali dalyvauti taktinėse pratybose, naudodamas imitacinius šovinius ir pirotechniką, taip pat kovinio šaudymo ir granatų metimo pratybose. Paskutinis kario rengimo šaudyti iš kovinio ginklo etapas yra kovinio šaudymo taktikos pratybos (isakymas „Dèl Sausumos pajègu kovinio rengimo standartinių veiklos procedūrų tvirtinimo“, 2017). Sausumos pajègų vado patvirtintas algoritmas kartu su privalomų užsièmimų su ginklais sąrašu, ị kuri itraukti ,techniniai taktiniai duomenys, apibūdinimas, ginklo saugumo patikrinimas, ginklo išardymas, valymas ir surinkimas, dètuvès užpildymas, ginklo užtaisymas, ištaisymas, taikiklio nustatymas, ginklo darymas saugiu, ginklo perdavimas, užsièmimų 1, 2, 3 praktika, nedelstini veiksmai ginklui užstrigus, kiti strigimai ir jų šalinimas, šaudymo padètys, šaudymas atsižvelgiant ị vejjo stiprumą ir kryptị “ (ịsakymas „Dẻl Sausumos pajègų kovinio rengimo standartinių veiklos procedūru tvirtinimo“, 2017, p. 4) sudaro tvirtą karių metodinio rengimo valdyti ginklą, kai tik to reikès, pagrindą ir yra geras iniciatyvos pavyzdys, kuriuo reikètų sekti.

Pagal Lietuvos kariuomenès šaulio rengimo sistemą karys yra neefektyviai 
rengiamas šaudyti iš pistoleto. Visų pirma todèl, kad nėra reglamentuota, ko ir kokia apimtimi jis turi būti mokomas prieš laikant GVT, o vẻliau kario mokymas vyksta jau šaudant. Pats GVT yra labiau orientuotas ị saugumo reikalavimų tikrinimą, kad karys gebètų šaudydamas saugiai atlikti manipuliacijas su ginklu. JAV sausumos pajègų kariai prieš laikydami teorijos ir praktikos ginklo valdymo testus turi būti išèję šias temas: amunicijos identifikavimas, ginklo saugumo taisyklès, ginklo saugumo statusai, pistoleto veikimo principas, šaudymo komandos, dètuvių keitimas (greitas, taktinis), taiklaus šaudymo principai ir parengimas testavimui, pistoleto priežiūra, ginklo veikimo patikrinimas (Headquarters, 2019, p. D-5). Pirmaisiais tarnybos metais Lietuvos karys, kuriam priskirtas ginklas, turi šaudyti pagal visu etapų - nuo 1 iki 4 - reikalavimus, bet antraisiais metais jam privalomas tik KŠIGT. JAV sausumos pajègų karių mokymo šaudyti iš pistoleto strategijoje numatytas net atskiras parengiamasis etapas: 2 - pradinis kovinio šaudymo imitavimas (angl. preliminary life-fire simulation), kurio metu naudojamos pažangiausios imitavimo technologijos, o Lietuvoje net labai paprastos ir prieinamos ,sausos“ treniruotès (be šaudymo, ịprastai be amunicijos arba naudojant mokomuosius šovinius) nèra aprašytos ir jų nereikalaujama.

Dviejų mokymo programų sugretinamas leido pamatyti šaulių rengimo galimybes. Visu pirma GVT laikyti besirengiantys kariai turi ne tik išmanyti ginklą, mokèti saugiai su juo elgtis, bet ir naudoti ji praktiškai mūšio sąlygomis greitai reaguodami ị taikinị ir taikliai iššaudami, taip pat ịgyti kitų būtinų ịgūdžių. Jų rengimas prasideda standartiškai, t. y. nuo supažindinimo su mokymo tikslu ir siekiniais, o tada jau kryptingai reikia dirbti su turiniu ir siekti ji efektyviai igyvendinti. Be techninių dalykų - greitų veiksmų su ginklu, - gyvybiškai svarbus yra psichologinis ginklo valdymo aspektas ir streso veiksnys, pradedant rengimą. Taip pat ir karių rengimas daryti fizini poveikį priešininkui - jị sustabdyti, sužeisti, jam atimti gyvybę (jị nužudyti) - neturètų būti paliktas nuošalyje. Siekiant kompleksinio šaulių rengimo, galima būtų ịtraukti streso valdymo, psichologinio atsparumo ugdymo ir šaudymo ịūdžių neịprastomis aplinkybèmis treniravimo pratimų. Kaip teigia Bratton (2015), rengiant policijos pareigūnus akcentuojama, kad šaunamasis ginklas naudojamas siekiant sustabdyti (angl. shoot to stop): pareigūnas turi nuspręsti, kokia fizinè jèga yra pagrịsta ir būtina, nes dažnai užtenka tik vieno šūvio tikslui pasiekti. Policijos pareigūnams pasakyta, kad jie nešaudo, kad nužudytų, o yra mokomi sustabdyti priešininką. Dėl to, kad stresas, patiriamas ginklo panaudojimo situacijose, gali pakenkti igūdžiams, ir dèl tam tikro pistoletų netikslumo policijos pareigūnai mokomi šaudyti ị priešininko kūno centrą, paprastai ị liemenị. Petersson et al. (2017) atskleidžia, kad labai svarbus yra pareigūnų pasirengimas, nes nuo to priklauso, ar jie tinkamai atliks savo funkcijas:

- didelès grèsmès incidento metu pareigūnas gali nespèti panaudoti ginklo, nes suabejos savo veiksmų teisètumu; tai atsitinka dèl nepakankamo policijos pareigūnų teisinio išsilavinimo arba neaiškios teisinès bazès;

- detali instrukcija (schema, algoritmas), kurioje aiškinama, kaip turi elgtis 
policijos pareigūnas užpuolimo atveju, turètų pagelbèti jam priimti tinkamą sprendimą;

- policijos pareigūnai turi būti treniruojami veikti pavojingose situacijose, kai yra didelè grèsmè.

Šaulių rengimo metu stengiamasi pateikti realesnius hipotetinius pareigūnų užpuolimo scenarijus. Pareigūnai turi mokytis atremti įvairius priešininkus (puolančius su įvairiais ginklais) ir ịvairiu atstumu, šaudyti ị judančius arba stacionarius taikinius, nesitaikant per kryptuką ir taikiklį, viena ranka ir judèdami.

JAV ir Lietuvos kariuomenès šaudymo iš pistoleto rengimo metu nekreipiama dèmesio į psichologinį karių pasirengimą šaudyti. Petersson teigia, kad susišaudymo metu policijos pareigūnus veikè stresas, kuris neleido jiems išnaudoti visų savo ịgūdžių, nes stresinèse situacijose tai priklauso nuo to, kaip įgūdžiai buvo formuojami ir tobulinami (Masters, 1992; Maxwell, Masters, Kerr ir Weedon, 2001).

Kompleksinis požiūris leistų sustiprinti šaulių parengtị, neskirstant jų ị pėstininkus ir kitus karius, bet rengti juos atsižvelgiant ị būsimų operacijų sudètingumą, asmeninių savybių ir turimų streso valdymo ịgūdžių skirtumus. Pateikta principinè šaulio rengimo sistemos schema, kuri dèl savo turinio ir dèl to, kad apima individualujji ir kolektyvinị rengimą, turètų būti vadinama „Šaulio ir karinio vieneto rengimo sistema" (3 pav.).

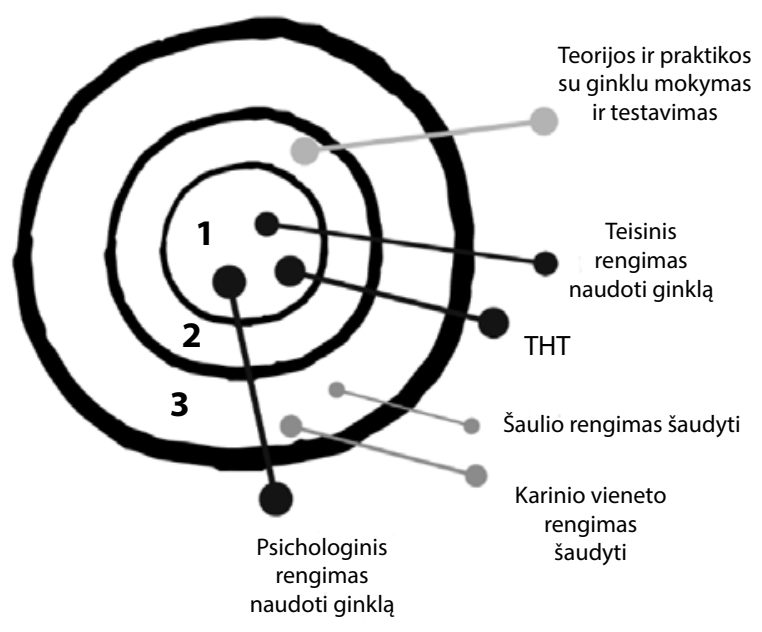

3 pav. Šaulio ir karinio vieneto rengimo sistema

Pavadinimas „Šaulio rengimo sistema“ turètų būti keičiamas, nes karys rengiamas ne tik kaip šaulys (individualusis rengimas), bet ir kaip karinio vieneto sudedamoji dalis (vykdomas kolektyvinis rengimas). Kariai, kaip ir policijos pareigūnai, turi gauti teisinị parengimą naudoti ginklą įvairiose situacijose, bet ypač svarbu gerai parengti kari savigynai. Kaip teigia Johnsenas ir kiti (2016), ịvairiais scenarijais pagrịstas mokymas turi tenkinti pareigūnų poreikius, kitaip sakant, turi 
būti individualizuotas, po teroristinio išpuolio detalios analizès, vertinant pareigūnų veiksmus ir teikiant rekomendacijas dèl mokymo programų tobulinimo, todèl pasiūlyta praplèsti lyderystès, psichologinị rengimą, taip pat mokyti veikti neapibrèžtomis sąlygomis (streso valdymas, sprendimų prièmimas stresinèse, nežinomose situacijose). Todèl būtina kariams suteikti ne tik tarptautinès humanitarinès teisès (THT) žinių, kas dabar atliekama nuotoliniu būdu, bet ir, išnaudojant nuotolinio mokymo teikiamus privalumus, praplèsti mokymą teisès ir psichologinio rengimo temomis ir siekiniais. Karys, atitikęs šiuos reikalavimus, būtų mokomas valdyti ginklą pagal sudarytą mokymo programą (remiantis individualiosiomis užduotimis) ir dalyvautu „teorijos ir praktikos su ginklu mokyme ir testavime“. Šis mokymas neturi apsiriboti GVT, testavimas turi būti kompleksinis, taip pat rekomenduojama ị jị ịtraukti rengimo pradžioje igytas kompetencijas. Šiame etape patartina naudoti ne tik lazerinị šaulių treniruoklį, bet ir kitas mokymo priemones, pvz., „Glock“ SIRT (lazerini „Glock“ ginklą), ir atitinkamai laiko skirti „,sausam“ (šaudymas be koviniu šovinių, tik šūvių imitavimas) šaulio rengimui. JAV kariuomenė jau naudoja virtualiosios realybès (VR) sistemas karių mokymui šaudyti ir priimti sprendimus, veikti taktinèse situacijose (Headquarters, 2019). Paskutiniame etape reikia rengti karius kaip šaulius ir tik vèliau karinius vienetus mokyti vykdyti kolektyvinio rengimo užduotis, ị kurias įtrauktas ir kovinis šaudymas. Pabrèžtina, kad šaulio (ne tik karinio vieneto) rengimą būtina vykdyti sudarant hipotetinius scenarijus taip, kad būtų testuojamos šaulių kompetencijos ir ịgūdžiai ne tik judèti, užimti įvairias šaudymo pozicijas, keisti detuves, taikliai šaudyti ir t. t., bet ir spręsti taktines dilemas kuo artimesnėmis mūšiui sąlygomis, pvz., skaičiuojant laiką ir taiklius šūvius.

\section{Išvados}

1. Lietuvos kariuomenès karys ir karinis vienetas turi būti rengiami šaudyti taikant „Šaudymo vadove“ aprašytus šaudymo reikalavimus. Karių rengimas, jo sudètingumas, dažnumas ir kario igytos testuojamos kompetencijos priklauso nuo trijų veiksnių: kario ištarnautų metų (pirmaisiais metais vykdomas sustiprintas rengimas), priskirto ginklo (individualus ar papildomas ginklas) ir dalinio paskirties (pėstininkų ar kitas vienetas). Tačiau vykdant karių rengimą šaudyti iš pistoleto

privalomus pratimus nustato dalinio vadas. „Šaudymo vadove“ pateikti šaudymo reikalavimai pėstininkams ir kitų padalinių kariams, nurodant konkrečias operacijas (pvz., puolimas, gynyba), gali būti klaidinantys, nes karinis rengimas planuojamas remiantis kariniam vienetui iškeltu uždaviniu ir aukštesniojo vado (karinio vieneto) uždavinio esminių užduočių sąrašu (UEUS) (Kolektyvinio rengimo vadovas, 2019). Lietuvos kariuomenè, suteikdama kariui teisę disponuoti šaunamuoju ginklu, turi tinkamai jị ir parengti. Iš kitų padalinių karių nereikalaujama gebėti naudoti ginklą greitai ir artimajame mūšyje, kas, manytina, nesudaro galimybių kariui igyvendinti savo teisès į savigyną. Palyginus rekomenduotinas kompetencijas, būtinas naudojant pistoletą artimajame mūšyje, su KŠIGT ir ŠPGĮ sudedamosiomis 
dalimis, galima teigti, kad kariai nèra mokomi ir testuojami, ar geba per nustatytą laiką išsitraukti pistoletą, ji užtaisyti ir taikliai iššauti, greitai keisti dètuves, šalinti ginklo užsikirtimo priežastis, šaudyti iki $15 \mathrm{~m}$ atstumu, taip pat kai ginklas dèkle yra užtaisytas.

2. Lyginant Lietuvos kariuomenès šaulio rengimo sistemą ir JAV kariuomenès sausumos pajègų šaudymo iš pistoleto šaudymo strategiją, taip pat Lietuvos ir užsienio policijos praktinę patirtį, galima padaryti šias išvadas:

2.1. Šaulių rengimo sistemos 1-ojo etapo pavadinime ir turinyje akcentuojamas tik GVT. Pagal JAV šaudymo iš pistoleto rengimo strategiją, visiems kariams privalomas individualusis rengimas. Karys turi atitikti visus standartus, rodydamas savo ịgūdžius, o teorijos testo rezultatas turi sudaryti 80 proc. ir daugiau. Reikalavimai turi būti ịvykdyti ne anksčiau kaip prieš 6 savaites iki kovinio šaudymo.

2.2. JAV rengiant karius naudojami virtualiosios realybès, lazeriniai imitatoriai šaulių igūdžiams formuoti, Lietuvos kariai virtualiosios realybès sistemų neturi, o lazeriniai šaulių treniruokliai skirti tik blogiau šaudantiems kariams treniruoti ir jų yra labai ribotas skaičius.

2.3. Švedijos policija 42 proc. atvejų pistoletus naudojo iki $3 \mathrm{~m}, 23$ proc. atveju - iki $7 \mathrm{~m}$ ir tik 18 proc. - nuo 7 iki $15 \mathrm{~m}$ atstumu. JAV policijos, skirtingu tyrimų duomenimis, iki 13,71 m (15 jardų) pistoletai naudoti 94-96 proc. visu atvejų. JAV kariuomenès sausumos pajègų kariai treniruojami šaudyti nuo 7 iki $31 \mathrm{~m}$ atstumu ị vieną arba du vienu metu rodomus taikinius, o Lietuvos kariai mokomi šaudyti nuo 10 iki $25 \mathrm{~m}$ ir testuojami nuo 15 iki $25 \mathrm{~m}$ atstumu.

Praktinè policijos pistoletu naudojimo patirtis atskleidè, kad riboto matomumo sąlygomis pistoletai buvo naudoti 59-77 proc. visų atvejų. 37 proc. atvejų policijos pareigūnai iš pistoleto šaudè viena ranka, 56 proc. atvejų - stovèdami, 33 proc. - judèdami ir net 11 proc. - iš padèties ,,sèdint“.

2.4. Šaulio rengimo sistema neatitinka ne tik sajungininkų rengimo metodikos, bet ir policijos pareigūnų pistoleto naudojimo praktinių aspektų.

3. Praktinis kario rengimas šaudyti iš pistoleto ịprastai užtrunka mintinai mokantis ginklo valdymo testo (GVT) reikalavimus ir juos atkartojant, nors oficia-lus reikalavimas yra, kad „kariai, pirmą kartą laikantys GVT, turi būti išėję visą mokymo su ginklu programą (pagal kovinio rengimo nuostatas turi būti organizuotas mokymas (pradinis rengimas, ịgūdžių formavimas, ịgūdžių ịtvirtinimas)“ (Šaudymo vadovas, 2020, p. 1-2). Minèta programa neegzistuoja arba jos nepavyko rasti. „Šaudymo vadove“ išdèstyta šaulio rengimo sistema turètų būti keičiama, kad būtų užtikrinamas tinkamas karių parengimas. Karių mokymo naudoti pistoletą programoje turètų būti nustatyti individualių užduočių šaudant iš skirtingų ginklų atlikimo standartai (IUAS) ir kaip privalomas reikalavimas ịtraukti i ‘ „Šaudymo vadovą“. Karių teisinis ir psichologinis parengimas sudaro sąlygas greitai ir tinkamai panaudoti ginklą pavojingose situacijose. Pavadinimas „Šaulio rengimo sistema“ turètų būti pakeistas, nes karys rengiamas ne tik kaip šaulys (individualusis rengimas), bet ir kaip karinio vieneto sudedamoji dalis (vykdomas kolektyvinis rengimas). 


\section{Literatūra}

Aveni, T. J. (2003). officer-involved shootings: what we didn't know has hurt us. The Police Policy Study Council. Law \& Order Magazine, (Hendon Media Group. Deerfield, IL).

Avis, J. (2018). Socio-technical imaginary of the fourth industrial revolution and its implications for vocational education and training: A literature review. Journal of Vocational Education and Training, 70 (3), 337-363, https://doi.org/10. 1080/13636820.2018.1498907

Bertilsson, J., Niehorster, D. C., Fredriksson, P. J., Dahl, M., Granér, S., Fredriksson, O., ... Nyström, M. (2019). Stress levels escalate when repeatedly performing tasks involving threats. Frontiers in Psychology, 10(JULY), 1-12, https://doi.org/10.3389/fpsyg.2019.01562

Bratton, W. J. (2015). New York City Police. Annual Firearms Discharge Reports, 2014. New York.

Čigrin, V. (2012). Aktyvaus mokymosi metodų naudojimas rengiant policijos pareigūnus. Visuomenés saugumas ir viešoji tvarka, 7(9), 93-102.

Čigrin, V. (2014). Studentų būsena prieš egzaminą ir jos sąsaja su rezultatais. Visuomenès saugumas ir viešoji tvarka, 2035, 45-54.

Čigrin, V. (2016a). Šaudymo mokymo proceso optimizavimo ypatumai: šūvio taiklumas. Visuomenès saugumas ir viešoji tvarka, 2035 (2016), 45-53.

Čigrin, V. (2016b). Šaunamojo ginklo panaudojimo praktika policijos veikloje 2015 metais. Visuomenès saugumas ir viešoji tvarka, 2035, 51-63.

Čigrin, V. (2017). Šaudmens efektyvumas arba stabdomoji kulkos galia. Visuomenès saugumas ir viešoji tvarka, 2035, 254-267. Retrieved from http:// www.mruni.eu/kpf_dokumentai/fakultetas/Leidiniai/MRU VSVT (18).pdf.

Headquarters, D. of the A. (2019). Training and qualification - individual weapons. (July). Retrieved from https://armypubs.army.mil/epubs/DR_pubs/DR_a/ pdf/web/ARN19574_TC_3-20.40-Incl_C1_FINAL_WEB.pdf.

Johnsen, B. H., Espevik, R., Saus, E. R., Sanden, S., \& Olsen, O. K. (2016). Note on a Training Program for Brief Decision Making for Frontline Police Officers. Journal of Police and Criminal Psychology, 31(3), 182-188, https://doi. org/10.1007/s11896-015-9180-7.

Kayihan, G., Ersöz, G., Özkan, A., \& Koz, M. (2013). Relationship between efficiency of pistol shooting and selected physical-physiological parameters of police. Policing: An International Journal of Police Strategies \& Management, 36(4), 819-832, https://doi.org/10.1108/PIJPSM-03-2013-0034.

Kolektyvinio rengimo vadovas. (2019). Kolektyvinio rengimo vadovas (A-LK-07.2). Vilnius: Mokymo ir doktrinų valdyba.

Krašto apsaugos ministerija. Koviniu ginklu ir specialiuju priemoniu naudojimo krašto apsaugos sistemoje tvarkos aprašas, (2008).

Lietuvių kalbos išteklių sistema. (n. d.). Retrieved on: July 19, 2020, from 
http://lkiis.lki.lt/dabartinis.

Lietuvos karinių pajègų rengimo doktrina. (2013). Lietuvos kariniu pajėgu rengimo doktrina (D-LK-07) (Patikslinta, G. Sadaitis, Ed.). Retrieved from https:// kariuomene.kam.1t/1t/kariuomenes_struktura/mokymo_ir_doktrinu_valdyba/lk_ doktrinos.html (1992).

Lietuvos Respublikos Konstitucija. Lietuvos Respublikos Konstitucija,

Lietuvos Respublikos Seimas. Krašto apsaugos sistemos organizavimo ir karo tarnybos istatymas, (1998).

Lietuvos Respublikos Seimas. Lietuvos Respublikos baudžiamojo kodekso patvirtinimo ir ìsigaliojimo istatymas, Pub. L. No. VIII-1968 (2000).

Lietuvos Respublikos terminų bankas. (n.d.-a). Retrieved July 19, 2020, from http://terminai.vlkk.lt/paieska?search=karinis+vienetas

Lietuvos Respublikos terminų bankas. (n.d.-b). Retrieved July 19, 2020, from http://terminai.vlkk.lt/paieska?search=batalionas

Masters, R. S. W. (1992). Knowledge, knerves and know-how: The role of explicit versus implicit knowledge in the breakdown of a complex motor skill under pressure. British Journal of Psychology, 83(3), 343-358; https://doi. org/10.1111/j.2044-8295.1992.tb02446.x

Maxwell, J.P., Masters, R.S.W., Kerr, E. \& Weedon, E. (2001). The implicit benefit of learning without errors. The Quarterly Journal of Experimental Psychology, 54A (4)(2010), 1049-1068.

McElvain, J. P., \& Kposowa, A. J. (2008). Police officer characteristics and the likelihood of using deadly force. Criminal Justice and Behavior, 35(4), 505521. https://doi.org/10.1177/0093854807313995.

Pataševas, V. (2002). Policijos tarnybinio ginklo naudojimo problemu sprendimas: trumpavamzdžiu ginklu tinkamumo tyrimas. 35(27), 64-73. Retrieved from $\mathrm{https}: / /$ search.proquest.com/docview/1426845644?pq-origsite $=$ gscholar\&fro mopenview $=$ true

Petersson, U., Bertilsson, J., Fredriksson, P., Magnusson, M., \& Fransson, P. A. (2017). Police officer involved shootings-retrospective study of situational characteristics. Police Practice and Research, 18(3), 306-321. https://doi.org/10.1 080/15614263.2017.1291592

Šaudymo vadovas. (2020). Šaudymo vadovas (A-LK-07.1.01.1). Vilnius: Mokymo ir doktrinų valdyba.

Sausumos pajègos. (2017). Isakymas „Dèl Lietuvos kariuomenès Sausumos pajégu vado 2014 m. gegužès 23 d. isakymo Nr. V-293 „Dèl Sausumos pajègu kovinio rengimo standartiniu veiklos procedūru tvirtinimo" papildymo". Vilnius.

Watts, B. (1996). Doctrine, Technology, and War. Retrieved from http://oai. dtic.mil/oai/oai?verb=getRecord\&metadataPrefix=html\&identifier=ADA331985.

Žydžiūnaite,, V. Sabaliauskas, S. (2017). Kokybiniai tyrimai: principai ir metodai: vadovélis socialiniu mokslu studiju programu studentams. Vilnius: VAGA. 


\title{
COMPLIANCE OF THE LITHUANIAN MILITARY \\ PISTOL SHOOTING TRAINING SYSTEM \\ WITH GLOBAL TRENDS
}

\author{
Laurynas Česūnas, Rosita Kanapeckaitė
}

General Jonas Žemaitis Military Academy of Lithuania

\begin{abstract}
The aim of the study is to reveal how pistol shooting methodology is used to train the servicemen of the Lithuanian Armed Forces as current annual testing shows that servicemen are not able to react quickly and use pistol in close combat conditions. It was found that the use of pistols by the U.S. and Swedish police officers at the distance of up to 15 meters, and in the case of the U.S. officers up to 15 yards, i.e. 13.7 meters, accounted for 83 percent and 96 percent of all weapon use, respectively. Swedish police officers used the gun at the distance of up to 3 meters in 42 percent of the collisions, whereas 50 percent of all gun use among the U.S. officers was up to 4.57 meters. Meanwhile, during the shooting test, Lithuanian officers shoot at a distance of 15-25 meters from individual and additional weapons. It is also revealed that the Shooting Manual stipulates that servicemen must undertake the entire training program on the weapon use prior to shooting from a pistol. Nevertheless, there is no such program. The analysis of the literature suggests that the Lithuanian Armed Forces Shooting Training System needs to be reviewed and redesigned and the changes should be based on scientific research and advanced didactic and methodological principles.
\end{abstract}

The problem of the research: current military pistol shooting training system used in the Lithuanian Armed Forces does not enable servicemen to use a pistol quickly in close combat conditions.

The aim of the research: to reveal the problems of the Lithuanian military pistol shooting training system in preparing servicemen to shoot from a pistol and provide recommendations on how to improve shooting training.

The object of the research: Lithuanian military pistol shooting training system.

Research tasks:

1. To describe the Lithuanian military pistol shooting training system;

2. To compare the military pistol shooting training system of the Lithuanian Armed Forces with the aspects of similar training systems in other countries and their practical use;

3. To reveal the problems of the military pistol shooting training system in preparing servicemen to take the weapon control test and to provide guidelines for the improvement of the system.

Research methods: analysis of scientific and methodological literature and documents, comparison and interpretation of statistical data, synthesis.

Keywords: shooting, infantry, small arms, pistols. 


\section{AUTORIŲ LYDRAŠTIS}

Autoriaus vardas, pavardė: Laurynas Česūnas

Mokslo laipsnis ir vardas: viešojo saugumo ir gynybos magistras

Darbo vieta ir pareigos: Generolo Jono Žemaičio Lietuvos karo akademija Autoriaus mokslinių interesų sritys: edukologija, andragogika, karių mokymo metodika, pažangūs mokymo metodai, šaudymo iš pistoleto metodikos

Telefonas ir el. pašto adresas: laurynas.cesunas@mil.lt.lt

Autoriaus vardas, pavardė: Rosita Kanapeckaitė

Mokslo laipsnis ir vardas: psichologijos magistre

Darbo vieta ir pareigos: Generolo Jono Žemaičio Lietuvos karo akademijos Lyderystès ugdymo centro vyr. psichologè

Autoriaus mokslinių interesų sritys: psichologinis atsparumas, lyderystè, vadovavimo psichologija

Telefonas ir el. pašto adresas: +37061564675 ;

rosita.kanapeckaite@gmail.com

\section{AUTHORS' COVER LETTER}

Author's name and surname: Laurynas Česūnas

Academic degree and name: Master of Public Security and Defence

Workplace and position: General Jonas Žemaitis Military Academy of Lithuania, Leadership and Methodological Development Centre, Senior Methodologist

Author's research interests: educology, andragogy

Telephone and e-mail address: laurynas.cesunas@mil.1t

Author's name and surname: Rosita Kanapeckaitė

Academic degree and name: Master of Psychology

Workplace and position: General Jonas Žemaitis Military Academy of Lithuania, Leadership and Methodological Development Centre, Senior Psychologist

Author's research interests: psychological resilience, leadership, management psychology

Telephone and e-mail address: +37061564675 , rosita.kanapeckaite@gmail.com 